\title{
Evaluation of a novel strategy, based in Coolant Flow Rate Control, for avoiding Knock in a Sl engine
}

\author{
Luigi Falbo ${ }^{1}$ \\ ${ }^{1}$ DIMEG - University of Calabria - Cube 44C - 87036 Rende (CS)
}

\begin{abstract}
An experimental study is carried out for investigating the possibility to limit knock occurrence on a SI engine by proper engine thermal management. The control of the wall temperature is realized by means of an electrically driven water pump. The coolant flow rate can be varied regardless of the engine speed. Preliminarily, an experimental campaign aimed at evaluating the effects of the coolant flow rate on the in-cylinder pressure fluctuations, under steady state engine operation, namely WOT@ $1500 \mathrm{rpm}$, is presented. In the experiments, the spark advance and the equivalence ratio are controlled by the ECU according to the production engine map and the coolant flow rate is varied from 1500 up to $4500 \mathrm{dm}^{3} / \mathrm{h}$. In a subsequent set of tests, a variation on spark advance is operated and, for each value of the spark advance, different coolant flow rates are enforced with the aim of evaluating the possibility to increase the spark advance as close as possible to the maximum brake torque condition and of mitigating knock occurrence with increased coolant flow rates. The benefits in terms of fuel economy and increase engine performance, in comparison to the traditional approaches for knock mitigation, are evaluated.
\end{abstract}

\section{Introduction}

The Spark ignition engines development is strongly influenced by the ability to contain the major problems affecting this technology. Research efforts are focused on both experimental and numerical investigations to enhance the engine performance and decrease pollutant emission, by the use of different advanced techniques [1-3]. Downsizing/turbocharging engines is now a daily challenge for manufacturers. No less important is the relevance of spark ignition engines for the development of hybrid cars. These important applications, therefore, lead the research towards the investigation of knock mitigation strategies to achieve high performance, reducing consumption and polluting emissions. Knock mitigation is a problem which has extensively been studied and which has affected much research over the past years. These researches have led to the implementation of consolidated and effective techniques for the reduction of pressure oscillations inside the cylinder. The most used techniques are: delay of the spark advance (SA); increase of fuel octane number; mixture enrichment; recirculation of exhaust gases (EGR) and water injection [4, 5]. Knock is a phenomenon strongly influenced by the temperature of the mixture [6]. For this reason, the goal of reducing temperature of fresh charge represents an interesting challenge, especially in conditions of maximum load and low engine speed, in which usually the mixture ignition is delayed to avoid auto-ignition.

Practical approaches to enhance the cooling process include modifications of the cooling system architecture as well as coolant flow rate and/or coolant temperature management strategies $[7,8]$. Therefore, temperature decrease and the consequent lower tendency to knock allow to get closer to the optimal spark advance, this can leads to significant advantages in terms of performance (IMEP, Torque). Recent study showed that an enhanced cooling strategy can effectively suppress knock by reducing the charge temperature, leading to an improvement in the thermal efficiency [9].

Recently, Cho et al. [10] studied the wall temperature effects on the end gas during each phase of an engine cycle, The lowering coolant temperature of about $15^{\circ} \mathrm{C}$ allows an increase of knock limit spark advance (KLSA) of about $4.2^{\circ} \mathrm{CA}$ at 
$1500 \mathrm{rpm}$ and $5^{\circ} \mathrm{CA}$ at $2000 \mathrm{rpm}$. Moreover, they showed that the head temperature decreasing has a grater effect then that of the liner.

Nishino et al. [11] have proved in their study that it is possible to reduce the temperature of fresh mixture during compression stroke increasing heat transfer flow between cylinder wall and coolant, adding new passing ways in the metal, therefore, increasing the total heat exchange area. In particular, their tests have shown that a reduction of about $20^{\circ} \mathrm{K}$ on cylinder head, cylinder block and piston surface leads overall to a spark advance gain of about $2.5^{\circ} \mathrm{CA}$.

Shih et al. [12] have deepen the issue of improving thermal efficiency as a way to increase torque and reduce fuel consumption, obtaining improvements regarding the knock tendency. They found that optimizing water jacket significantly improved the uniformity of cylinders in terms of knock limited ignition timings. The bench test results confirmed that new water jacket design results in about 2.3\% increase of engine WOT torque and 2.2\% reduction of fuel. Furthermore, low temperature of cylinder wall leads to an increase of SA from $2.5^{\circ} \mathrm{CA}$ at $3000 \mathrm{rpm}$, up to $3.5^{\circ} \mathrm{CA}$ at $5000 \mathrm{rpm}$.

Fukuda et al. [13] employed a dual cooled system that allowed the achievement of a $6.3^{\circ} \mathrm{CA}$ advancement in ignition timing, an additional $1.6^{\circ} \mathrm{CA}$ advancement with a wall temperature reduction of about $10 \mathrm{~K}$ and an output torque improvement of about $2.5 \%$.

The objective of the proposed work is to expand, through other solutions, the techniques for lowering the temperature of the engine wall. In particular, it is proposed to manage the coolant flow rate using an electric pump, which allows to choose the desired coolant flow rate regardless of the engine speed and also allowing further advantages, such as lowering polluting emissions and fuel consumption reduction with respect to the traditional cooling system in standard homologation cycle [14]. Electric water pump application, with control of coolant flow rate, represents a simple and reliable technical choice that can allow immediate benefits. This solution introduces very few changes that only consist in the replacement of the mechanical pump with the electric one and in the use of pipes with a larger diameter to avoid high speed. This experimental campaign starts from results founded in previous work [15], in which was demonstrated, that using higher coolant flow rate and reaching lower wall temperature, it is possible to contain the amplitude of pressure oscillations inside the cylinder. In the previous work a less powerful water pump was utilized, nevertheless, there were clear benefits, with a reduction of $\mathrm{KI}_{\mathrm{th}}$ from 0.39 bar to 0.27 bar, respectively with $500 \mathrm{dm}^{3} / \mathrm{h}$ and $2500 \mathrm{dm}^{3} / \mathrm{h}$ of coolant flow rate.

In this work is investigated the possibility to enhance the SA to achieve the optimum spark advance in stationary condition WOT@1500rpm. Increase the SA leads to major knock tendency but using higher coolant flow rate, up to $4500 \mathrm{dm} 3 / \mathrm{h}$, help to contain the rise of high frequency pressure waves. Test bench results show that it is possible to achieve a spark advance gain, similar to Nishino [11] and Shih [12] spark advance gain, with a different cooling strategy.

\section{Experimental set-up}

The experimental activity is carried out on a small naturally aspirated four-stroke spark ignition engine, $1.2 \mathrm{dm}^{3}$ displacement with four in-line cylinders and four valves per cylinder, which develops a maximum power of about $60 \mathrm{~kW}$ between 5000 and $6000 \mathrm{rpm}$. The experimental apparatus is shown in Fig.1. The stationary test rig is equipped with an eddy current engine torque dynamometer (Borghi\&Saveri FE 260-S), is provided with an actuator for the remote control of throttle position and with a fuel metering system (AVL 733S) for fuel consumption measurements.

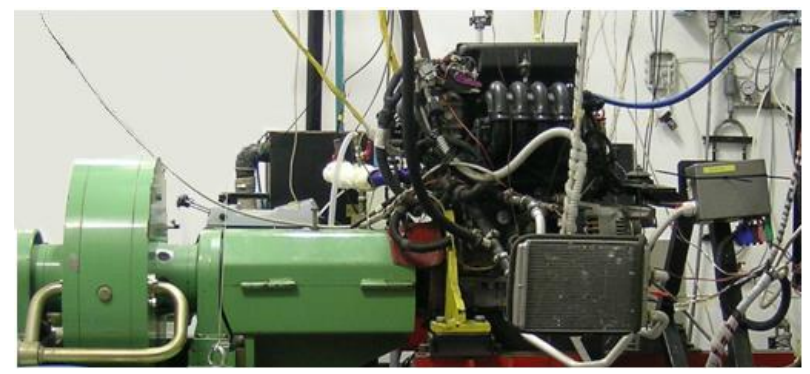


Fig. 1. Experimental test rig for the $1.2 \mathrm{dm}^{3}$ engine.

The metal temperature is measured in various locations of the cylinder block (head gasket side) and in the cylinder head by means of K-type thermocouples, as displayed in Fig.2. The hottest cylinder is cylinder \#2 and will be used as a reference for in-cylinder pressure measurements.

An electrically driven pump substitutes the standard crank-shaft driven one for the management of the coolant flow rate independently of engine speed. The electrically driven pump is produced by OMP Company and the technical specifications are reported in Table 1. The coolant flow rate is measured through an electromagnetic flowmeter (PROLINE PROMAG E 100). Coolant temperature and pressure sensors are installed at engine inlet and outlet. The cooling system layout of the experimental test rig is considerably modified with respect to the production engine cooling system with the aim to include coolant temperature and pressure sensors and a coolant flow meter, as displayed in Fig. 2. The inlet temperature is kept constant by using a PID control, whereas the thermostatic valve at engine outlet is removed.

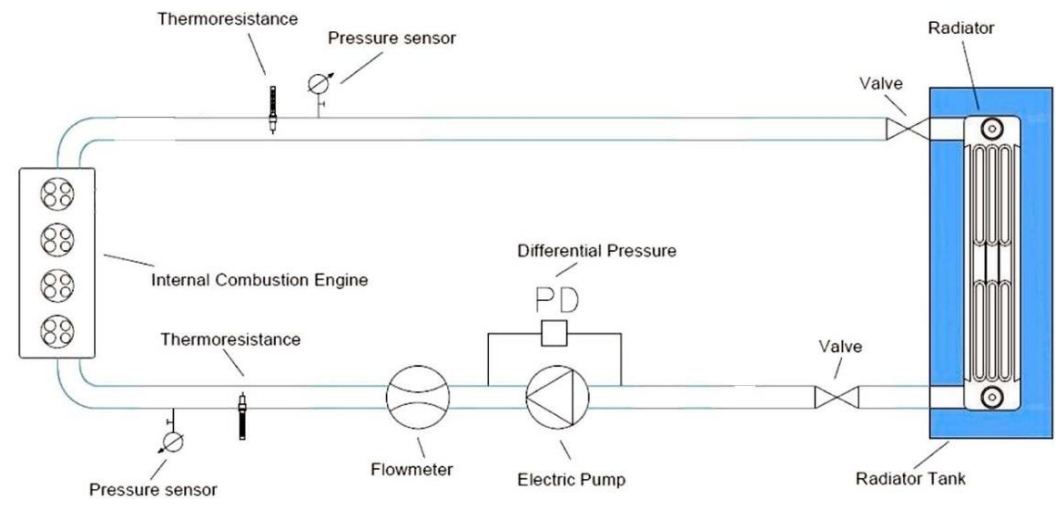

Fig. 2. Engine cooling system schematic.

The engine is equipped with an indicating measurement system for the instantaneous in-cylinder pressure and crank angle. In particular, a spark-plug with an integrated pressure sensor (AVL ZI33 Y5D) is located in the hottest cylinder (Cylinder \#2 in Fig.3) and a crankshaft encoder (AVL 365 C) allows the measurement of the crank angle. The pressure signal analysis is carried out by means of the charge amplifier, AVL INDIMICRO 602, and the IndiCom software.

The main specifications of the instrumentation are reported in Table 2. 


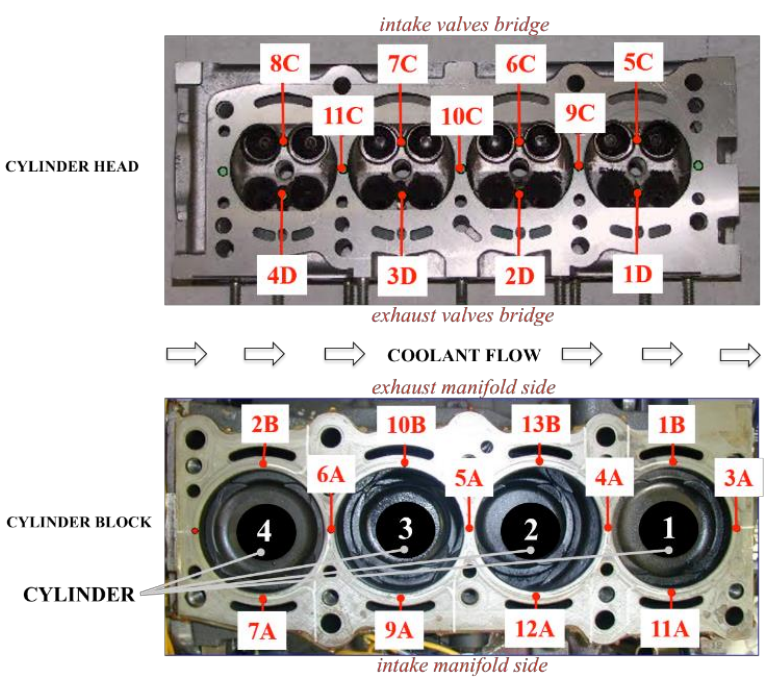

Fig. 3. Thermocouples location in the engine metal.

Table 1. Technical specifications of the electrically driven pump.

\begin{tabular}{|c|c|}
\hline Maximum flow rate & $240 \mathrm{l} / \mathrm{min}$ \\
\hline Maximum electric power & $1000 \mathrm{~W}$ \\
\hline Input Voltage & $12 \mathrm{~V}$ \\
\hline Maximum motor speed & $5000 \mathrm{rpm}$ \\
\hline Overall efficiency & $67 \%$ \\
\hline
\end{tabular}

Table 2. Main measurement devices specifications.

\begin{tabular}{|c|c|c|}
\hline Device type & Model & Specifications \\
\hline $\begin{array}{l}\text { BORGHI\&SAVERI, eddy current } \\
\text { dynamometer }\end{array}$ & FE $260 \mathrm{~S}$ & $\begin{array}{c}\text { FS } 190 \mathrm{~kW} @ 12000 \mathrm{rpm} \\
\text { Speed measurement: FS } \\
20000 \mathrm{rpm} \text {, resolution } 1 \\
\text { revolution, accuracy } \pm 1 \\
\text { rpm revolution } \\
\text { Torque measurement: FS } \\
2000 \mathrm{Nm} \text {, resolution 1 } \\
\text { digit, accuracy } \pm 0.1 \% \mathrm{FS} \text {. }\end{array}$ \\
\hline AVL, fuel meter & $733 \mathrm{~S}$ & $\begin{array}{c}\mathrm{FS} 150 \mathrm{~kg} / \mathrm{h} \\
\text { Sensitivity and linearity } \\
\text { deviation } \pm 0.12 \% \text { of the } \\
\text { fuel mass withdrawn. }\end{array}$ \\
\hline ENDRESS+HAUSER, flow meter & Promag E 100 & $\begin{array}{c}\text { FS } 3001 / \mathrm{min} \\
\text { Repeatability } \pm 0.5 \% \text { of } \\
\text { reading. }\end{array}$ \\
\hline $\begin{array}{l}\text { AVL spark-plug with integrated } \\
\text { pressure sensor }\end{array}$ & ZI33 & $\begin{array}{c}\text { FS } 200 \text { bar } \\
\text { Linearity } \leq \pm 0.3 \% \\
\text { Natural freq. } 150 \mathrm{kHz}\end{array}$ \\
\hline
\end{tabular}




\begin{tabular}{|c|c|c|}
\hline Pt100 temperature sensor & TRC\#P1A1X & $\begin{array}{c}\text { FS } 120^{\circ} \mathrm{C} \\
\text { Precision } \pm 0.15^{\circ} \mathrm{C}\end{array}$ \\
\hline K-type thermocouples & & $\begin{array}{c}\text { FS } 1000{ }^{\circ} \mathrm{C} \\
\text { Precision } \pm 1.5^{\circ} \mathrm{C}\end{array}$ \\
\hline KULITE, pressure sensor & ETQ-12-375 & $\begin{array}{c}\text { FS } 10 \text { bar } \\
\text { Resolution infinitesimal } \\
\text { Bandwidth } 3 \mathrm{kHz}\end{array}$ \\
\hline
\end{tabular}

\section{Methodology}

Several experimental tests are carried out in order to evaluate the effects of the coolant flow rate on knock mitigation. To this aim, a preliminary set of experiments regards the engine operating under steady state conditions, namely at wide open throttle (WOT) and $1500 \mathrm{rpm}$ engine speed, with the spark advance and the equivalence ratio as defined by the production ECU. In this case, different coolant flow rates, varying from 1500 up to $4500 \mathrm{dm}^{3} / \mathrm{h}$, are operated by the electric pump in order to evaluate the effects of an increase in coolant flow rates on pressure oscillations.

In a further experimental campaign, the engine operating conditions (WOT@1500 rpm) is left unchanged and a variation on spark advance is operated. For each value of the spark advance, different coolant flow rates are enforced with the aim to evaluate the possibility to increase the spark advance ad close as possible to the maximum brake torque condition and by mitigating knock occurrence with increased coolant flow rates.

For each tested case, the benefits in terms of fuel economy and increase engine performance, in comparison to the traditional approaches for knock mitigation, are evaluated. All tests are carried out with commercial gasoline, RON $\Rightarrow 5$. For each test, the in-cylinder pressure signal acquisition occurs over 1000 cycles, with a 0.1 crank angle sampling frequency.

There are many methods utilized for knock characterization [4]. In this study, the analysis of pressure inside the cylinder is used, following techniques applied in literature [16 - 18]. For each cycle, it is filtered by means of a high-pass filter from $4 \mathrm{kHz}$, in the crank angle window $60^{\circ}$ BTDC $-60^{\circ}$ ATDC. The maximum of the absolute values of this filtered signal is the knock intensity $(\mathrm{KI})$, which is helpful in discriminating knocking cycles. The results of the experimental campaign are presented and discussed in the next section.

\section{Results and discussion}

\subsection{Fixed Spark Advance and coolant flow rate variation}

The experimental campaign is carried out with the engine operating under steady state conditions, namely at 1500 rpm engine speed and wide-open throttle (WOT), which, for the considered engine, corresponds to 8.5 bar bmep. Knock intensity (KI), defined as the amplitude of the oscillations as recorded by the pressure transducer [1, 2], is used as a metric for knock occurrence. A subjective threshold value is set up so that a specific engine cycle is knocking if the cycle KI $>1$ bar, while an operating point (load, speed, $\lambda$ ) is in knock condition if more than $10 \%$ of all cycles are knocking [6]. For this purpose, the cumulative frequency distribution of $\mathrm{KI}$ has been evaluated for each test condition and the threshold $\mathrm{KI}$ value, $\mathrm{KI}_{\text {th }}$, corresponding to the 90 th percentile of the cumulative frequency distribution of $\mathrm{KI}$ is evaluated.

The effects of a coolant flow rate variation on pressure oscillations are evaluated. In particular, a coolant flow rate of 1500 $\mathrm{dm}^{3} \mathrm{~h}$ is preliminarily enforced. This value corresponds to the value delivered by the standard belt-driven pump at $1500 \mathrm{rpm}$ for the considered engine. Subsequent tests are carried out with higher coolant flow rate values amounting to 2500,3500 and $4500 \mathrm{dm}^{3} / \mathrm{h}$, respectively. Independently on the enforced coolant flow rate, the spark advance is the one determined by the manufacturer and is fixed at $6^{\circ}$ BTDC; the mixture at full load is slightly enriched $(\lambda=0.93)$ as set in ECUby the manufacturer.

Figure 4 shows the cumulative frequency distribution of KI for the engine operating condition characterized by WOT @ 1500 $\mathrm{rpm}$ and $\lambda=0.93$, for the considered values of coolant flow rate. With a coolant flow rate of $1500 \mathrm{dm}^{3} / \mathrm{h}$, the threshold KI is about 0.50 bar, which is far below the occurrence of light knock. With increasing the coolant flow rate, the wall temperature 
reduces, and the KIth reduces as a direct consequence, reaching the value of KIth $=0.24$ bar for the highest coolant flow rate $\left(4500 \mathrm{dm}^{3} / \mathrm{h}\right)$. This indicates that, despite the engine operating condition is far from knock occurrence, as expected, with reducing the metal temperature, the pressure oscillations considerably decrease, with a beneficial effect on knock prevention.

Figure 5 shows the KI trend for the operating condition WOT@ 1500 rpm with two different coolant flow rates: $1500 \mathrm{dm}^{3} / \mathrm{h}$ (red) and $4500 \mathrm{dm}^{3} / \mathrm{h}$ (blue). The trend of the KI in Fig. 5 confirms the benefit of the greater cooling, that leads to a significant reduction in the knock tendency of each cycle, also affecting the maximum value. This maximum KI value goes from 1.75 bar for $1500 \mathrm{dm}^{3} / \mathrm{h}$ to 0.60 bar for $4500 \mathrm{dm}^{3} / \mathrm{h}$ of coolant flow rate.

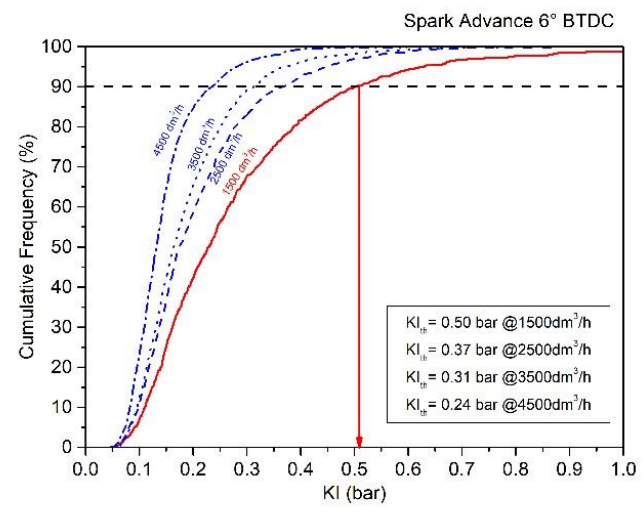

Fig. 4. Cumulative frequency distribution of Knock Intensity (KI) for the engine operating at WOT @1500rpm, for different coolant flow rates, $\mathrm{SA}=6^{\circ} \mathrm{BTDC}$.

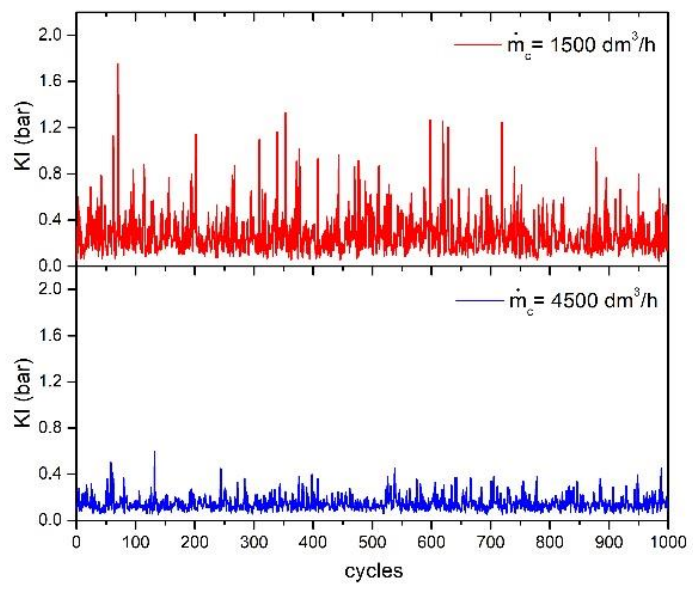

Fig. 5. Knock Intensity (KI) distribution for the engine operating at WOT @ $1500 \mathrm{rpm}, \mathrm{SA}=6^{\circ} \mathrm{BTDC}$, with two different coolant flow rates: $1500 \mathrm{dm}^{3} / \mathrm{h}$ (red); $4500 \mathrm{dm}^{3} / \mathrm{h}$ (blue).

Table 3 summarizes the main thermal parameters of the engine, during the experimental tests. For each test, the inlet/outlet coolant temperatures, TC,in and TC,out, the outlet coolant pressure, pout, and the NB_Index are measured. The NB_Index, 
in particular, is a metric, defined in [4] for estimating the distance of the system from the onset of nucleate boiling. A negative $\mathrm{NB}$ Index indicates that the heat transfer is limited to forced convection only; nucleate boiling occurs when positive $\mathrm{NB}$ _Index values are obtained; $\mathrm{NB}$ _Index $\approx 1$ denotes saturated boiling. The metal temperature of one of the thermocouples, TW,2D, located in the metal head and the thermal power to the coolant, QC, and coolant pressure at engine outlet, $\mathrm{P}_{\mathrm{c}, \text { out }}$, are also included. The coolant temperature at engine inlet is kept at about $84^{\circ} \mathrm{C}$. At constant bmep, lower coolant flow rate gives higher coolant temperature and NB_Index, higher wall temperature and, therefore, increased knock tendency. It is worth pointing out that no nucleate boiling occurs $\left(\mathrm{NB} \_\right.$Index $\left.<0\right)$; the KI values, therefore, are not influenced by the implosion of vapor bubbles.

Table 3. Engine thermal parameters during experimental tests.

\begin{tabular}{|c|c|c|c|c|c|c|}
\hline mic $[\mathbf{d m 3} / \mathbf{h}]$ & Tc,in $\left[{ }^{\circ} \mathbf{C}\right]$ & $\mathbf{T c}$, out $\left[{ }^{\circ} \mathbf{C}\right]$ & $\begin{array}{c}\text { Pc,out } \\
{[\mathbf{b a r}]}\end{array}$ & $\mathbf{N B}_{-}$index & Tw,2D $\left[{ }^{\circ} \mathbf{C}\right]$ & $\mathbf{Q c}[\mathbf{k W}]$ \\
\hline 1500 & 84.5 & 92.3 & 1.67 & -0.30 & 186.8 & 12.0 \\
\hline 2500 & 83.0 & 88.3 & 1.70 & -0.45 & 182.6 & 13.7 \\
\hline 3500 & 84.1 & 88.1 & 1.76 & -0.55 & 180.6 & 14.4 \\
\hline 4500 & 83.8 & 87.1 & 1.85 & -0.63 & 180.4 & 15.3 \\
\hline
\end{tabular}

\subsection{Spark Advance and coolant flow rate variations}

The effects of a spark advance variation on knock intensity are evaluated. The main purpose of the experimental campaign is to evaluate the possibility to avoid the spark advance retard, which is usually adopted to prevent knock, by leaving its value as close as possible to the MBT condition and by mitigating the knock occurrence with a proper management of the coolant flow rate. The adopted SA values vary from $6^{\circ} \mathrm{BTDC}$, which is adopted by the production ECU for the engine operating at WOT@1500 rpm, to 9.2 BTDC in steps of 0.8 CA degrees. For each test, the coolant flow rate is kept constant and several values ranging from $1500 \mathrm{dm} 3 / \mathrm{h}$ to $4500 \mathrm{dm}^{3} / \mathrm{h}$ in steps of $1000 \mathrm{dm}^{3} / \mathrm{h}$ are considered. Finally, the pressure data acquisition is carried out over 1000 cycles.

Figure 6 shows the average value over 1000 acquisition cycles of signal of the in-cylinder pressure, for different values of spark advance and for a coolant flow rate of $1500 \mathrm{dm} 3 / \mathrm{h}$. The corresponding cumulative frequency distribution of knock intensity, for the same operating condition, is plotted in Figure 7.

Figure 8 shows that with a coolant flow rate of $1500 \mathrm{dm} 3 / \mathrm{h}$ and setting spark advance to $9.2^{\circ}$ BTDC, KIth is next to light knock threshold and there are 300 cycles (30\%) that is equal or exceed the value of 1 bar.

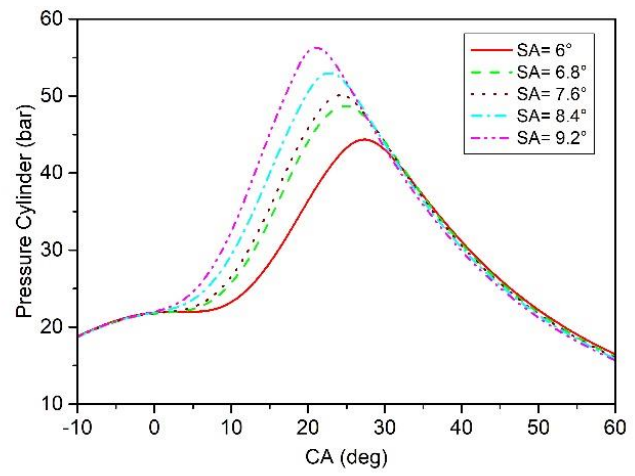

Fig. 6. In-cylinder pressure for different SA values. Engine operating point WOT@1500rpm, coolant flow rate 1500 dm3/h. 


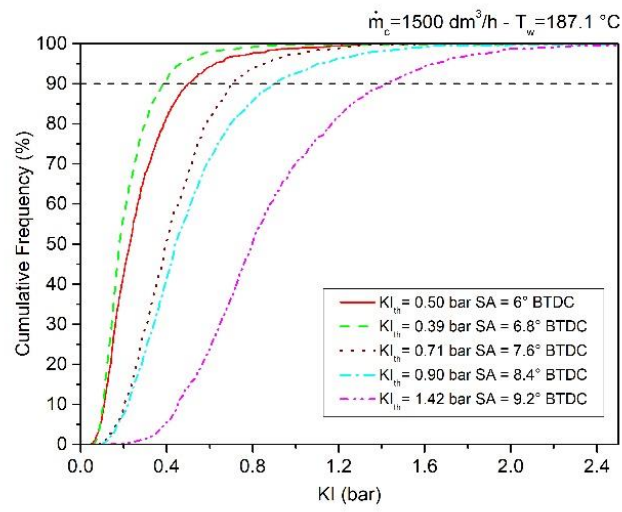

Fig. 7. Cumulative frequency distribution of Knock Intensity (KI) for different SA values. Engine operating point WOT@1500rpm, 1500 $\mathrm{dm} 3 / \mathrm{h}$ coolant flow rate.

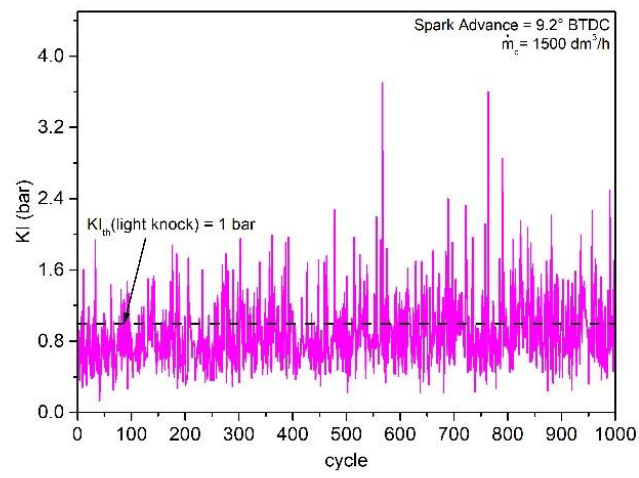

Fig. 8. Knock Intensity (KI) distribution for the engine operating at WOT @ $1500 \mathrm{rpm}, \mathrm{SA}=9.2^{\circ} \mathrm{BTDC}$, with $1500 \mathrm{dm} 3 / \mathrm{h}$ of coolant flow rates.

In this series of experiments, when the spark advance is increased, the production ECU slightly enriches the mixture and the equivalence ratio, which, with the standard spark advance is about $\lambda=0.93$, is reduced to $\lambda=0.88$ and is kept constant with further variations of the SA. Owing to mixture enrichment, the KIth, which is expected to increase with increasing the spark advance, slightly diminishes for the test with $\mathrm{SA}=6.8^{\circ} \mathrm{BTDC}$ if compared with the standard SA of $6^{\circ} \mathrm{BTDC}$ (Fig. 6). However, as expected, with further increasing the spark advance, the knock intensity increases and reaches its highest value for a spark advance of about $9.2 \mathrm{CA}$ degrees. The corresponding KIth value is about 1.42 bar. The results in terms of $\mathrm{KI}_{\mathrm{th}}$ for the tested spark advance values and coolant flow rates are summarized in Table 4.

Table 4. KIth values for different values of coolant flow rates and spark advance CA degrees.

\begin{tabular}{llllll}
\hline$\dot{m}_{\mathrm{c}}[\mathrm{dm} 3 / \mathrm{h}]$ & $6^{\circ} \mathrm{BTDC}$ & $6.8^{\circ} \mathrm{BTDC}$ & $7.6^{\circ} \mathrm{BTDC}$ & $8.4^{\circ} \mathrm{BTDC}$ & $9.2^{\circ} \mathrm{BTDC}$
\end{tabular}




\begin{tabular}{llllll}
\hline 1500 & 0.50 & 0.39 & 0.71 & 0.90 & 1.42 \\
2500 & 0.37 & 0.43 & 0.60 & 0.85 & 1.51 \\
3500 & 0.31 & 0.37 & 0.52 & 0.81 & 1.12 \\
4500 & 0.24 & 0.20 & 0.48 & 1.01 & 1.00 \\
\hline
\end{tabular}

It can be observed that, at a fixed coolant flow rate, the increase in spark advance contributes to increase the knock intensity. On the contrary, at a fixed spark advance, the increase of coolant flow rate has a beneficial effect on knock mitigation. This effect can be advantageously adopted; in fact, by increasing the coolant flow rate from $1500 \mathrm{dm}^{3} / \mathrm{h}$ to a value between 3500 and $4500 \mathrm{dm}^{3} / \mathrm{h}$, it is possible to increase the spark advance, obtaining therefore a higher brake torque, while keeping the similar knock intensity levels with the standard case, as shown in Table 5.

The increase in brake torque and the advantages evaluated in terms of indicated power and efficiency with increasing the spark advance are reported in Table 5.

Table 5. Engine performance for different values of spark advance.

\begin{tabular}{cccccc}
\hline $\begin{array}{c}\text { Spark } \\
\text { Advance } \\
{\left[\mathbf{C A}{ }^{\circ}\right.}\end{array}$ & $\begin{array}{c}\text { Brake } \\
\text { Torque } \\
{[\mathbf{N m}]}\end{array}$ & $\begin{array}{c}\text { Pb } \\
{[\mathbf{k W}]}\end{array}$ & $\begin{array}{c}\text { Pind } \\
{[\mathbf{k W}]}\end{array}$ & $\begin{array}{c}\text { BSFC } \\
{[\mathbf{g} / \mathbf{k W h}]}\end{array}$ & BTE[\%] \\
\hline 6 & 86.5 & 13.6 & 14.6 & 278.0 & 29.00 \\
6.8 & 89.3 & 14.0 & 15.3 & 287.8 & 27.80 \\
7.6 & 89.7 & 14.1 & 15.8 & 282.1 & 28.70 \\
8.4 & 90.0 & 14.1 & 16.2 & 283.7 & 28.50 \\
9.2 & 90.0 & 14.1 & 16.7 & 285.6 & 28.20 \\
\hline
\end{tabular}

With increasing the spark advance, as expected, the brake torque rises and the MBT condition is obtained with $\mathrm{SA}=8.4^{\circ}$; similarly, the indicated power considerably rises and an increase up to $14 \%$ is achieved from $6^{\circ}$ to $9.2^{\circ}$ spark advance. Notwithstanding an increase brake power is revealed, the BTE decreases of about $2.8 \%$ and an increase of $2.7 \%$ in BSFC is also observed. This is due to the mixture enrichment (from $\lambda=0.93$ at $6^{\circ} \mathrm{SA}$ to $\lambda=0.88$ for the other SA values) operated by the production ECU, which explains the reduction in engine efficiency from 6 to $6.8^{\circ}$. For further increase in the spark advance, the equivalence ratio is kept constant by the ECU and the efficiency reaches its maximum for $\mathrm{SA}=7.6^{\circ}$, which represents therefore an optimal operating condition, which allows a higher torque than the standard case and keeps the knock intensity levels far below the knock occurrence.

The achieved results are helpful for the definition of alternative approaches to the commonly adopted fuel consuming strategies for knock mitigation, based on the development of cooling strategies, which limit the spark advance retard and improve, therefore, the engine efficiency.

\section{Summary/Conclusions}

The tests were carried out using the heaviest stationary operating condition: WOT @ 1500rpm. In this operating condition, the influence of coolant flow rate on knock tendency, with spark advance set by the manufacturer, was assessed first. In the second part, the research focused on the possibility of being able to increase the spark advance by exploiting the beneficial effect of increasing the coolant flow rate. The experimental investigation has shown that through the use of a greater coolant flow rate it is possible to increase the spark advance towards the optimum value, increasing the brake torque and at the same time managing the knock tendency. Therefore, the replacement of the mechanical pump with an electric pump, with the possibility of coolant flow managing, represents an innovative and reliable solution to limit the amplitude of pressure oscillations inside the cylinder. The activity means to continue with the study of the combined effects of higher spark advance 
and higher coolant flow rate, however, assessed under transient load conditions, similar to the real engine operating condition. Another important step on which attention is focused is the employment of stoichiometric mixture at full load. It is interesting to investigate the possibility of working with stoichiometric mixture and at the same time avoiding auto-ignition that this operating condition can increase. Furthermore, this solution could lead to excellent results as regards the reduction of fuel consumption and the achievement of higher performance.

\section{References}

1. A. Algieri, M. Amelio, S. Bova, P. Morrone, "Energy Efficiency Analysis of Monolith and Pellet Emission Control Systems in Unidirectional and Reverse-Flow Designs", SAE International Journal of Engines March 2010 2:684-693

2. A. Algieri, S. Bova, C. De Bartolo, A. Nigro, "Numerical and Experimental Analysis of the Intake Flow in a High Performance Four-Stroke Motorcycle Engine", Journal of Engineering for Gas Turbines and Power, Vol. 129, n. 4, 2007.

3. A. Algieri, S. Bova, and C. De Bartolo, "Experimental and Numerical Investigation on the Effects of the Seeding Properties on LDA Measurements," ASME J. of Fluids Engineering, 127 N. 3, pp.514-522, 2005.

4. X. Zhen, Y. Wang, S. Xu, Y. Zhu, C. Tao, T. Xu, M. Song, “The engine knock analysis - An overview,” Applied Energy, Volume 92, 2012, Pages 628-636, ISSN 0306-2619, https://doi.org/10.1016/j.apenergy.2011.11.079.

5. Z. Wang, H. Liu, R.D. Reitz, "Knocking combustion in spark-ignition engines," Progress in Energy and Combustion Science, Volume 61, 2017, Pages 78-112, ISSN 0360-1285, https://doi.org/10.1016/j.pecs.2017.03.004.

6. J.B. Heywood, Internal Combustion Engine Fundamentals Second Edition (McGraw-Hill, 2018).

7. F. Fatigati, D. Di Battista, R. Cipollone, "Design improvement of volumetric pump for engine cooling in the transportation sector", Energy, Volume 231, 2021, 120936, ISSN 0360-5442, https://doi.org/10.1016/j.energy.2021.120936

8. M. Di Bartolomeo, F. Fatigati, D. Di Battista, R. Cipollone, "A new approach for designing a testing engine coolant pump electrically actuated", ," SAE Technical Paper 2020-01-1161, 2020, doi: https://doi.org/10.4271/2020-01-1161.

9. S. Cho, C. Song, N. Kim, S. Oh, D. Han, K. Min, "Influence of the wall temperatures of the combustion chamber and intake ports on the charge temperature and knock characteristics in a spark-ignited engine" Applied Thermal Engineering, Volume 182, 2021, 116000, ISSN 1359-4311, https://doi.org/10.1016/j.applthermaleng.2020.116000.

10. S. Cho, C. Song, S. Oh, K. Min et al., "An Experimental Study on the Knock Mitigation Effect of Coolant and Thermal Boundary Temperatures in Spark Ignited Engines," SAE Technical Paper 2018-01-0213, 2018, doi:10.4271/2018-010213.

11. Nishino, Tomoki and Nobuaki Murakami. "Study of Engine Cooling Technologies for Knock Suppression in Spark Ignition Engines.” Mitsubishi motors Technical review, 2004.

12. S. Shih, E. Itano, J. Xin, M. Kawamoto et al., "Engine Knock Toughness Improvement Through Water Jacket Optimization," SAE Technical Paper 2003-01-3259, 2003, https://doi.org/10.4271/2003-01-3259.

13. Y. Fukuda, H. Tawa, A. Makise, Increase of knock limit in outboard motor through employment of dual control direct cooling system, Honda R D Tech. Rev. 16 (2004) 121-126.

14. T. Castiglione, P. Morrone, L. Falbo, D. Perrone, S. Bova, Application of a Model-Based Controller for Improving Internal Combustion Engines Fuel Economy. Energies 2020, 13, 1148.

15. D. Perrone, L. Falbo, T. Castiglione, S. Bova, "Knock Mitigation by Means of Coolant Control," SAE Technical Paper 2019-24-0183, 2019, doi:10.4271/2019-24-0183.

16. K. Chun and J.B. Heywood, "Characterization of Knock in a Spark-Ignition Engine," SAE Technical Paper 890156, 1989 , https://doi.org/10.4271/890156.

17. M. Brunt, C. Pond, J. Biundo, "Gasoline Engine Knock Analysis using Cylinder Pressure Data," SAE Technical Paper 980896, 1998, https://doi.org/10.4271/980896.

18. E. Galloni, G. Fontana, S. Staccone, "Numerical and experimental characterization of knock occurrence in a turbocharged spark-ignition engine," Energy Conversion and Management, Volume 85, 2014, Pages 417-424, ISSN 01968904, https://doi.org/10.1016/j.enconman.2014.05.054. 
Contact Information

Luigi Falbo

DIMEG - Universita della Calabria - Cubo 44C - 87036 Rende

(CS-Italy)

luigi.falbo@unical.it

Definitions/Abbreviations

\begin{tabular}{|c|c|}
\hline ATDC & After Top Dead Center \\
\hline BMEP & $\begin{array}{l}\text { Brake Mean Effective } \\
\text { Pressure. }\end{array}$ \\
\hline BSFC & $\begin{array}{l}\text { Brake Specific Fuel } \\
\text { Consumption }\end{array}$ \\
\hline BTE & Brake Thermal Efficiency \\
\hline BTDC & Before Top Dead Center \\
\hline $\mathrm{CA}$ & Crank Angle \\
\hline ECU & Electronic Control Unit \\
\hline FS & Full Scale \\
\hline IMEP & $\begin{array}{l}\text { Indicated Mean Effective } \\
\text { Pressure }\end{array}$ \\
\hline KI & $\begin{array}{l}\text { Knock Intensity: } \\
\text { amplitude of the pressure } \\
\text { oscillation }\end{array}$ \\
\hline $\mathrm{KI}_{\text {th }}$ & $\begin{array}{l}90^{\text {th }} \text { percentile of the } \\
\text { cumulative frequency } \\
\text { distribution of KI }\end{array}$ \\
\hline MBF & Mass Burned Fraction \\
\hline MBT & Maximum Brake Torque \\
\hline $\mathrm{m}_{\mathrm{c}}$ & $\begin{array}{l}\text { Volumetric coolant flow } \\
\text { rate }\end{array}$ \\
\hline mif & Fuel consumption \\
\hline NA & Naturally Aspirated \\
\hline NB_index & Nucleate boiling index \\
\hline
\end{tabular}




$\begin{array}{ll}\mathrm{P}_{b} & \text { Brake Power } \\ \mathrm{P}_{\mathrm{c}, \text { out }} & \text { Coolant Outlet Pressure } \\ \mathrm{P}_{\text {ind }} & \text { Indicated Power } \\ \mathrm{Q}_{\mathrm{c}} & \text { Thermal Power to coolant } \\ \mathrm{SA} & \text { Spark Advance } \\ \mathrm{T}_{\mathrm{c}, \text { in }} & \text { Coolant Inlet Temperature } \\ \mathrm{T}_{\mathrm{c}, \text { out }} & \text { Coolant } \\ & \text { Temperature } \\ \mathrm{T}_{\mathrm{w}, 2 \mathrm{D}} & \begin{array}{l}\text { Temperature } \\ \text { thermocouple 2D }\end{array} \\ \mathrm{WOT} & \text { Wide Open Throttle } \\ \eta_{\mathrm{g}} & \text { Global efficiency } \\ \boldsymbol{\lambda} & \text { Air-fuel equivalence ratio }\end{array}$

